\title{
The New Manifestations of External Debt in Developing Countries From 2000 to 2019
}

\author{
Vu Thi Kim Hanh \\ Van Lang University, 45 Nguyen Khac Nhu Street, Co Giang Ward, District 1, Hochiminh City, Vietnam
}

\begin{abstract}
The paper analyzes the new manifestations of external debt in developing countries from 2000 to 2019, author uses the analytical qualitative and quantitative method, the findings are (1) the external debt is trended by groups of country, (2) external debt stocks of PPG long term debt, PNG long term debt rose between 2000 and 2019, (3) The percentage of GDP of External debt stocks decreased, PNG long term debt and short term debt slightly went up between 2000 and 2019, (4) East and South-East Asia and Oceania and Latin America and the Caribbean have exchange the top and second position of highest amount in both 2018 and 2000, (5) Debt service on long-term external PPG of SIDS is helds the biggest amount of debt between 2000 and 2019, (6) The redemption schedules of both High-income countries and Low- and middle-income countries both increased the amount of redemption which is from around 2 to 2.32 tril USD and 0.67 to 1.07 tril USD in 2000 and 2021, respectively. This shows us that at least they have solution how to get resolved their external debt.
\end{abstract}

KEYWORDS: external debt, developing countries

\section{INTRODUCTION}

The global scale of external debt of developing countries has been become the greatest from twentieth century. The debt crisis is to prove as an unprecedented phenomenon to the world economy. The direct reason of occurrence of the global debt is that the market economy leading increasing the commodity exchange between well developed countries and the countries still considered as developing countries. To a great extent, that phenomenon occurred due to the loans given by the richer countries to the countries that were worse developed- though- it should be noted that also welldeveloped countries ran into debt (Grzegorz Górniewicz, 2009). As per the study of David Simon in 2020, " The debt crisis has been with us for approaching half a century and, despite many initiatives by creditors and indebted countries, it is unlikely to disappear in the foreseeable future. The structural as well as proximate causes of the global debt crisis that erupted in the early 1980 s are outlined as context to examination of the anatomy of indebtedness as it has subsequently evolved and mutated differentially in various regions of the Global South and transitional economies. Several global initiatives have sought to tackle the problem in different ways since the 1980s, ranging from outright debt forgiveness to structural adjustment. The longest lasting is the Highly Indebted Poor Country Initiative and its enhanced sequel, the Multilateral Debt Relief Initiative. Their record has been mixed and some countries are now again facing unsustainable levels of total external debt through a mixture of inappropriate domestic policies, fluctuating terms of trade, and a failure to tackle the global structural causes of indebtedness".

\section{LITERATURE REVIEW}

The basic cause of the occurrence of external debt of developing countries is due to the open of industrialized countries and their expansion. The least develop countries and the developing countries cannot join the global market and are not able to abey and follow the rules that apply by the developed countries. External debts, purposed is to accelerate the economic growth of developing countries and to make the considerable differences in economic level void, became the future restraint of development that bore negative influence on financial condition of states. Underde- veloped countries remained passive receivers who cannot afford (Grzegorz Górniewicz, 2009). The status of bebt heaviness of Korea manageable and within expectation. However, the concern over increasing short-term debt with fluctuating interest rates because of the constraints produced on the process of economic adjustments to changing world conditions. Besides, the long-term debt service ratio is shown to be inadequate, as it indicates overall debt burden and servicing needs of a borrowing country when asset preferences have been undergoing shifts toward short-term obligations. The implications related to debt issue of developing countries are a strong expansion in world trade is essential for decreasing economic and financial costs of external debt conditions. The skill improvement how to manage debt and flexibility in the economic structure are also essential for reducing the economic costs of the external debt on developing economies, 
because they increase a country's ability to rapidly bring about a manageable debt level. Basically, external debt issue is a monetary phenomenon of both a local and global nature in a world characterized by its growing interdependence. Therefore, solutions should be devised accordingly. However, the current difficulties hould be resolved through global efforts, Once they are mitigated, one can then turn to the question of how the external debt was created at such a high level in the first place (SungY. Kwack, 1983). External debt has strong influence making negative effect on growth in comparison with domestic debt when indebtedness increases. debt has a negative effect on economic growth in the long term. A nonlinear analysis reveals an asymmetric outcome of external debt on economic growth. Export and total factor productivity as key economic control variables contribute significantly to economic growth (Keshmeer Makun, 2021). Study of Marin Ferry, MarcRaffinot, Baptiste Venet in 2021 found out that "the debt relief has fostered borrowing from private creditors, and identify the absence of reputational effects and the short-term horizon of private creditors as the key drivers that made renewed access to the credit market possible". As by study of Gatien Bon and Gong Cheng in 2021 found out that "China has been increasingly involved in debt restructurings for low- and middle-income countries like Iraq (2003), Cuba (2010), Seychelles (2011), Chad (2017), Zambia (2018), Mozambique (2018), Cameroon (2019), Republic of Congo (2019) and Venezuela (in progress). The magnitude of China's debt relief actions remains generally limited and varies across countries, depending on whether other creditors have also provided debt restructurings. China seems to have a growing preference for cancellation of accumulated arrears to nominal debt principal reduction. The debt rescheduling cases have significantly increased in recent years as well. This evolution brings China closer to the flow treatment that the Paris Club privileged in its early years of operations and the prevailing practices among private creditors". In China, technological innovation effect is offset by the investment substitution effect that leads to an overall nonsignificant impact on the debt ratio. Therefore, the impacts on debt ratio by brownfield investment and the outward foreign direct investment destined for less developed countries are not apparent.In comparison, the greenfield investment andthe OFDI destined for developed countries lead to anincreased debt ratio (Zhenbing Yang, Zhuo Chen, Qi Shi al et, 2021). The study of David Simon in 2020 stated that "The largest absolute external debtors are middle-income or, like China and India, economically fast-growing countries. Not all of these are experiencing the heaviest debt burden; the weight of the burden depends on the ability of a country to service its debt. Although the US government is by far the world's largest debtor, being unable to cover its fiscal deficit (which stood at $\$ 8.348$ trillion in late May 2006). Nevertheless, it is salutary to note that this debt was more than three times higher than the total external debt of all low- and middle-income countries in 2005". By study of Xuguang
Simon Sheng, Rubena Sukaj in 2020 shows that "External debt shocks for 120 low- and middle-income countries during the 1975-2018 period lead to persistent decreases in the external debt to GDP ratio, possibly due to the availability of other sources of financing. During recessionary episodes, however, we see heavy reliance on external debt financing for most of developing countries. This reliance is more substantial for countries with higher levels of external debt stock, raising serious concerns for debt distress in these countries and in their road to building resilience". The estimation results reveal insignificant positive impact of both external debt and export on economic growth, in the shortrun. The impact turns negative in the long-run. Some policy options may be considered included the curtailing of external borrowing until current debt stocks are repaid, ensuring external loans are tied to specific projects to avoid inefficient allocation of the funds, exploring domestic capital market for funds as alternative to external borrowing (Samson Edo, Nneka Esther Osadolor, Isuwa Festus Dading, 2020).

\section{METHODOLOGY}

Qualitative method by three following steps:

Step 1: Collect information of debt of developing countries through internet, World Bank (WB), United Nations Conference on Trade and Development (UNCTAD), International Monetary Fund (IMF), United Nation (UN), published papers, newspapers

Step 2: Deeply studying Global Development Finance External Debt of Developing Countries which published by WB and report of Development statistics and information branch of UNCTAD

Step 3: Analyzing the the bebt status of developing countries Quantitative method: having statistics, analyzing by charts.

\section{DATA SOURCE}

All data are from UNCTAD WB, Economist Intelligence Unit (EIU), and Institute of International Finance (IIF)

\section{THEORETICAL BASIS}

Definition of External Debt of WB in 1988, "The agreed core definition of external debt is gross external debt is the amount, at any given time, of disbursed and outstanding contractual liabilities of residents of a country to non-residents to repay principal, with or without interest, or to pay interest, with or without principal".

Definition of External Debt by IMF in 2003 is 'The Guide defines gross external debt as follows: Gross external debt, at any given time, is the out-standing amount of those actual current, and not contingent, liabilities that require payment(s) of principal and/or interest by the debtor at some point(s) in the future and that are owed to nonresi- dents by residents of an economy".

According to the Economic Times, "Definition of External Debt is to refer to money borrowed from a source outside the country. External debt has to be paid back in the currency in 
which it is borrowed. External debt can be obtained from foreign commercial banks, international financial institutions like IMF, World Bank, ADB etc and from the government of foreign nations. Normally these types of debts are in the form of tied loans, meaning that these have to be used for a predefined purpose as determined by a consensus of the borrower and the lender. Government and corporations are eligible to raise loans from abroad. These are in the form of external commercial borrowings. The interest rate on foreign loans is linked to LIBOR (London Interbank Offer rate) and the actual rate will be LIBOR plus applicable spread, depending upon the credit rating of the borrower".

\section{STUDY RESUTLS}

Figure 1. External debt stocks in developing countries

(Unit: Billions of current USD (Bil USD)

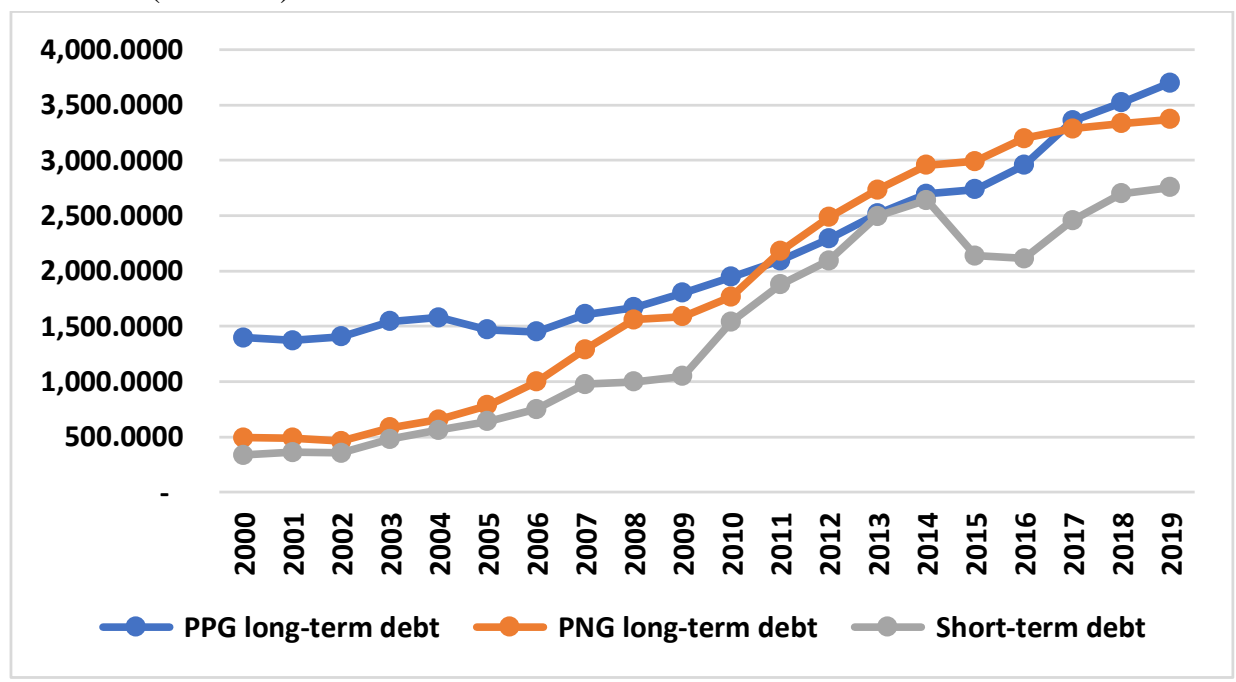

Source: Charted by author based on UNCTAD calculations based on data from WB and EIU.

Note: Figures for 2019 are UNCTAD estimates. PPG is Publicly Guaranteed Debt. PNG is Publicly Non-Guaranteed Debt

As figure 1 shows the stocks of PPG long term debt, PNG long term debt and short term debt were peaked in 2019 are around 3,750, 2,90, and 3,750 Bil USD, respectively. While
PPG long term debt, PNG long term debt rose over the period shown, short term debt was fluctuated between 2014 and 2019. Three kinds of debts have the smallest amount in 2000 but the highest is PPG long term debt at around 1,400 Bil USD, PNG long term debt is 500 Bil USD, and short term debt is roughly $300 \mathrm{Bil}$ USD.

Figure 2. External debt stocks as a percentage of GDP in developing countries

(Unit: Percentage $(\%)$ )

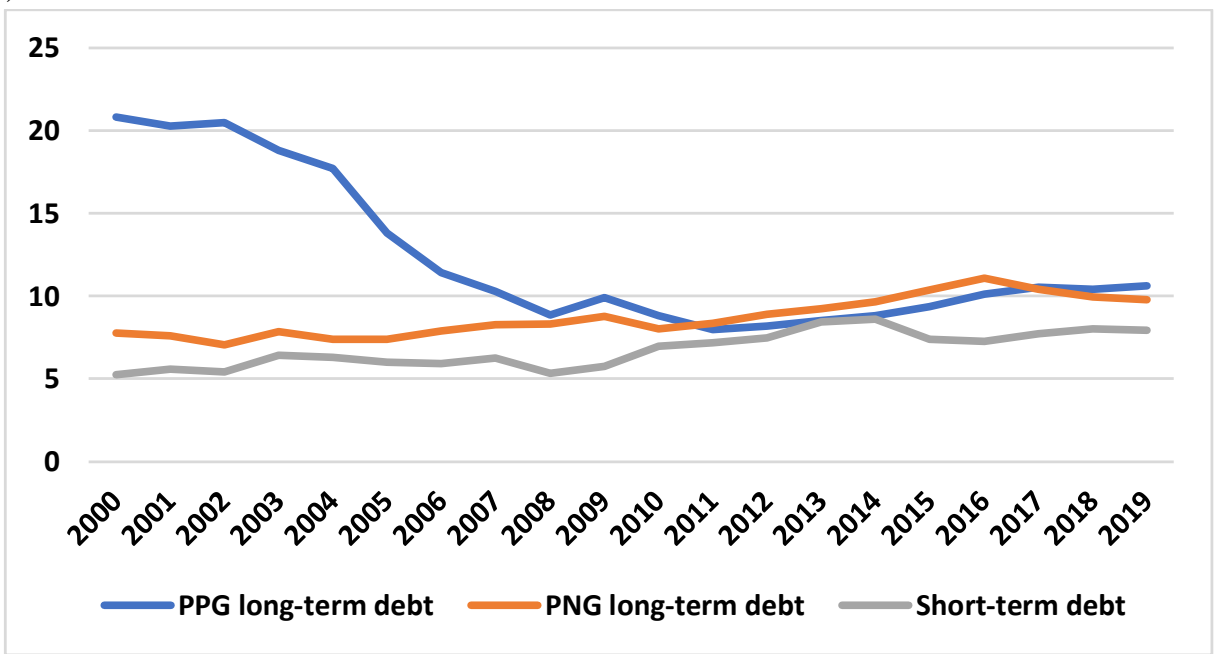

Source: Charted by author based on UNCTAD calculations based on data from WB, and EIU.

Note: Figures for 2019 are UNCTAD estimates.

This is of concern is while PPG long term debt decreased between 2000 and 2008, these other PNG long term debt and short term debt slightly went up during the period shown. In 2000, PPG long term debt got the biggest amount is $21 \%$, 
PNG long term debt and short term debt are approximately $7.5 \%$ and $5 \%$, respectively. Although PPG long term debt went down in 2019 at around $11 \%$ but still higher than PNG long term debt and short term debt which are roughly $10 \%$ and $7.5 \%$, respectively. All three kinds of debts did not have big different amount in 2013 that are less than $10 \%$.

Figure 3: External debt stocks in developing countries by region

(Unit: Bil USD)

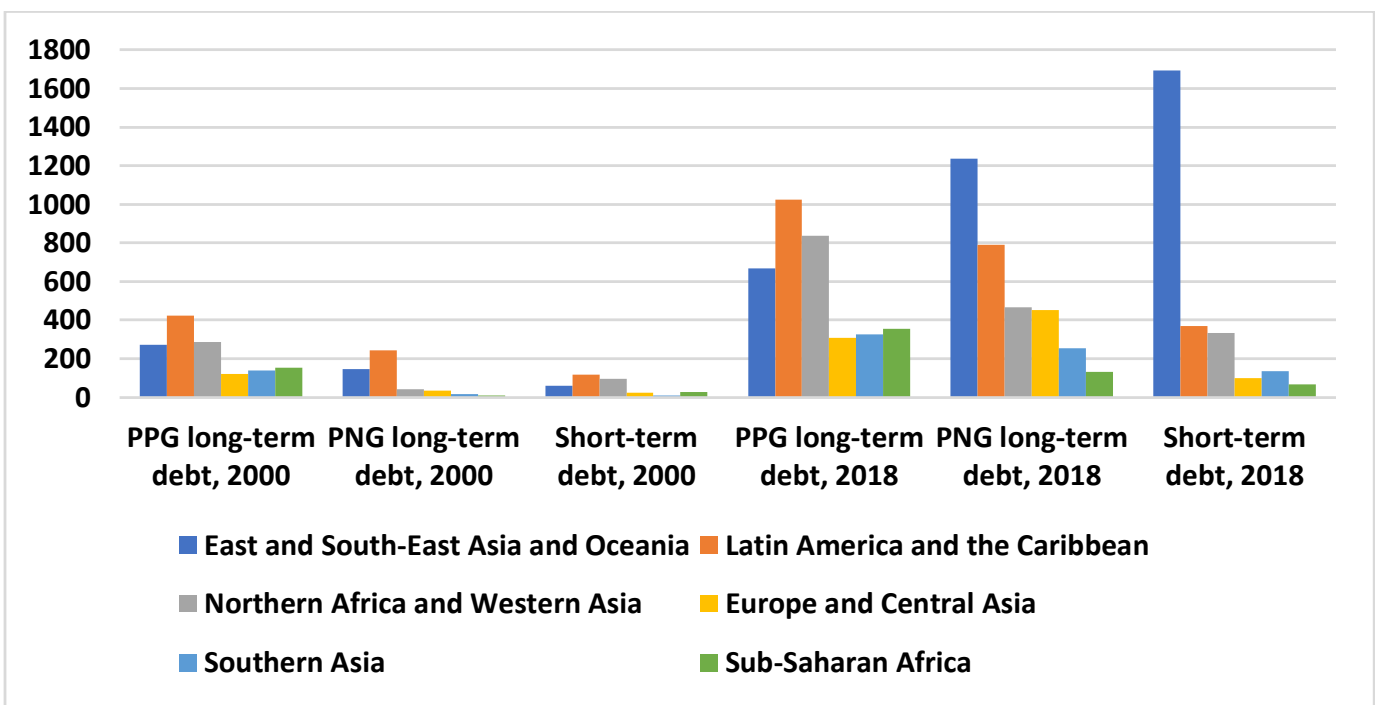

Source: Charted by author based on UNCTAD calculations based on data WB, and EIU.

Figure 3 shows external debt stocks in developing and transition countries by region in 2018 and 2000. Overall, all six regions decreased the amount of all three kinds of debts in 2000 in comparing with 2018. While, The highlight is the amount of PNG long term debt and short term debt in 2018 is small but increased strongly in 2020, especially East and South-East Asia and Oceania is nearly 272 Bil USD. The concern is East and South-East Asia and Oceania and Latin America and the Caribbean have exchange the top and second position of highest amount in both 2018 and 2000.

Figure 4. Long-term external PPG debt by creditor in developing countries (Percentage of total PPG debt $(\%)$ )

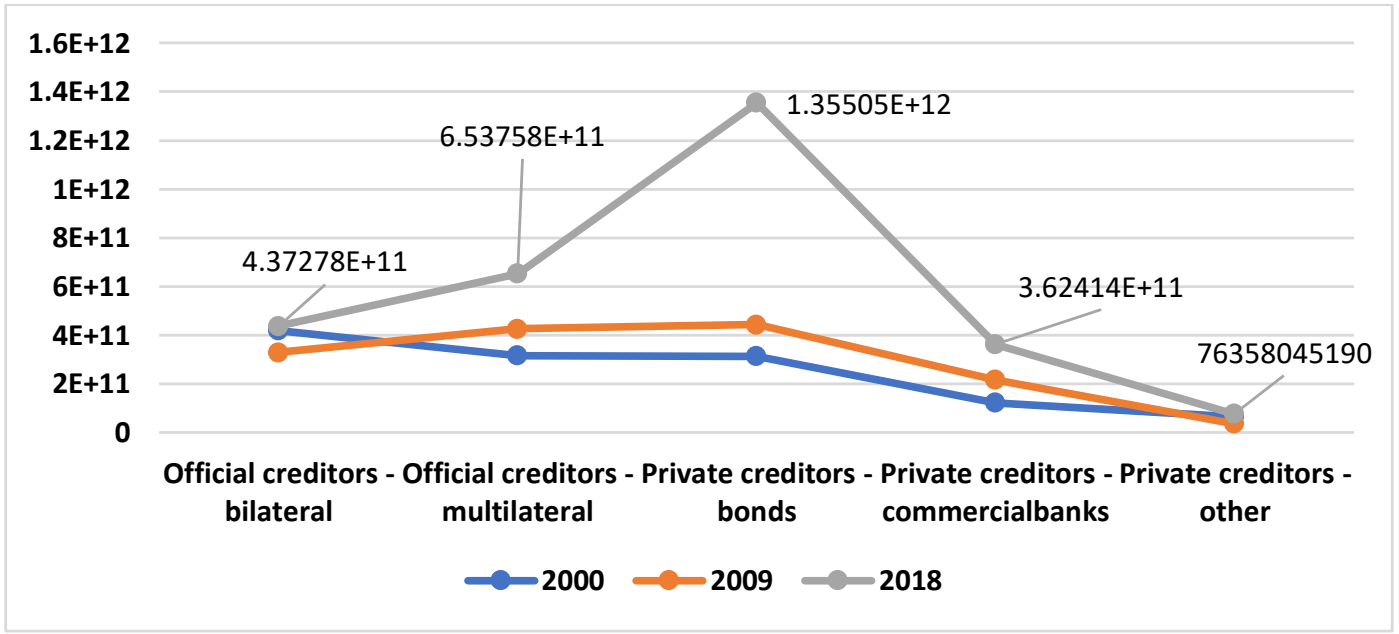

Source: Charted by author based on UNCTAD calculations based on data WB

Notes: Averages by group of economies. Only countries with available data were included.

This illustrates the amount of debt in 2018 is the highest over the period shown. While the debt of Private creditors - bonds in 2018 had an incredibe increase and reached the peak, 2000 and 2009 is slightly increased. On other hand, private creditors - bonds helds the biggest amount for average three years, especially $1.35505 \mathrm{E}+12 \%$ in 2018.2000 and 2009 are not strong difference of fluctuation, the blue and orange lines are nearly running between the originating and destination points. 
Figure 5. Debt service on long-term external PPG debt in developing countries (Percentage $(\%)$ of exports of goods and services)

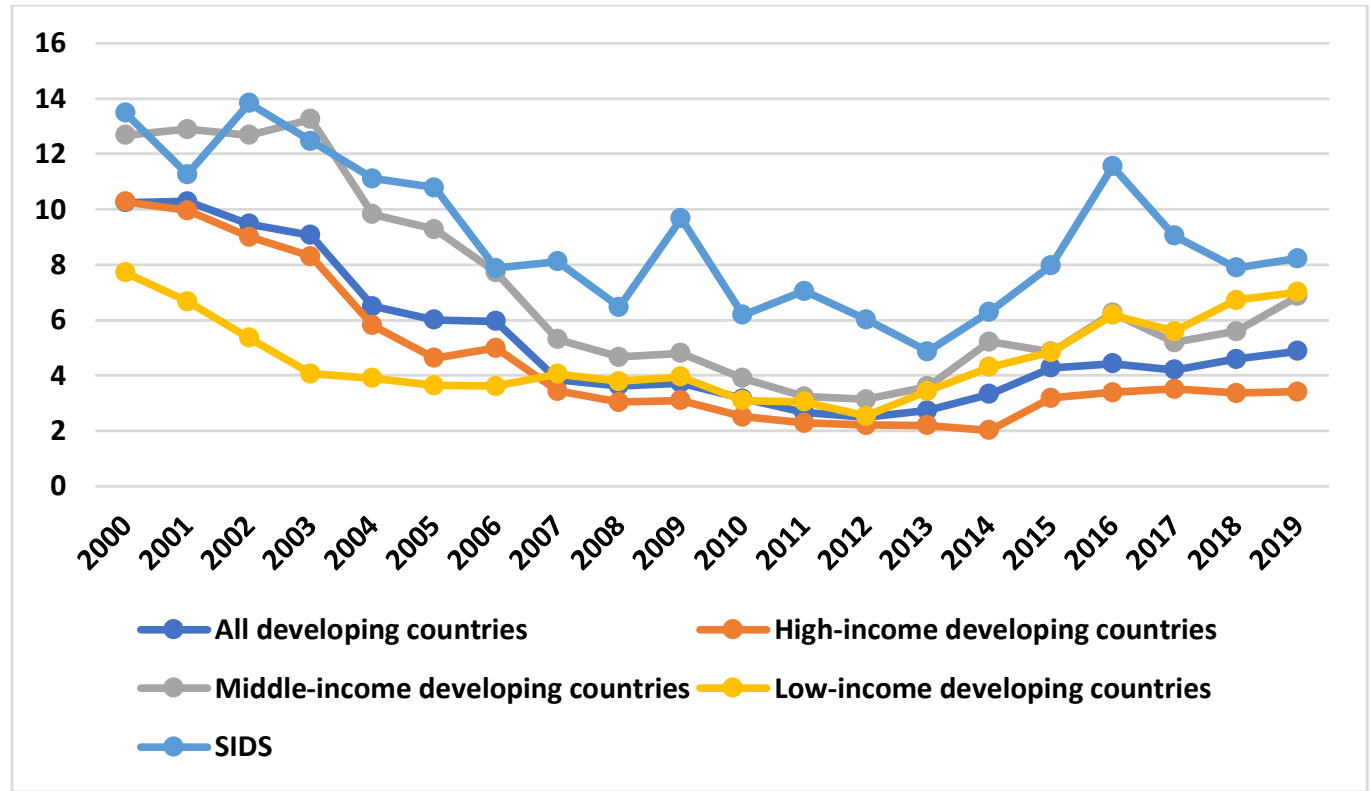

Source: Charted by author based on UNCTAD calculations based on WB, EIU

Notes: Figures for 2019 are UNCTAD estimates. Income groups follow WB's definition; small island developing states (SIDS) group follows UNCTAD's definition.

As figure 5 shows us information that we can compare the status bebt of developing countries in detail. In which the overall is SIDS is helds the biggest amount of debt between 2000 and 2019. High-income developing countries and lowincome developing countries are not much different even generally low-income developing countries likely to be softer at the figure is under $8 \%$ in 2000 and decreased until 2003, got fluctuated until 2019 with slightly increased at approximetely $7 \%$. The groud of middle-income developing countries seem to held the heavier debt than others.

Figure 6. Debt service on long-term external PPG debt, Low-income group and Sub-Saharan Africa group of developing countries (Percentage $(\%)$ of government revenue)

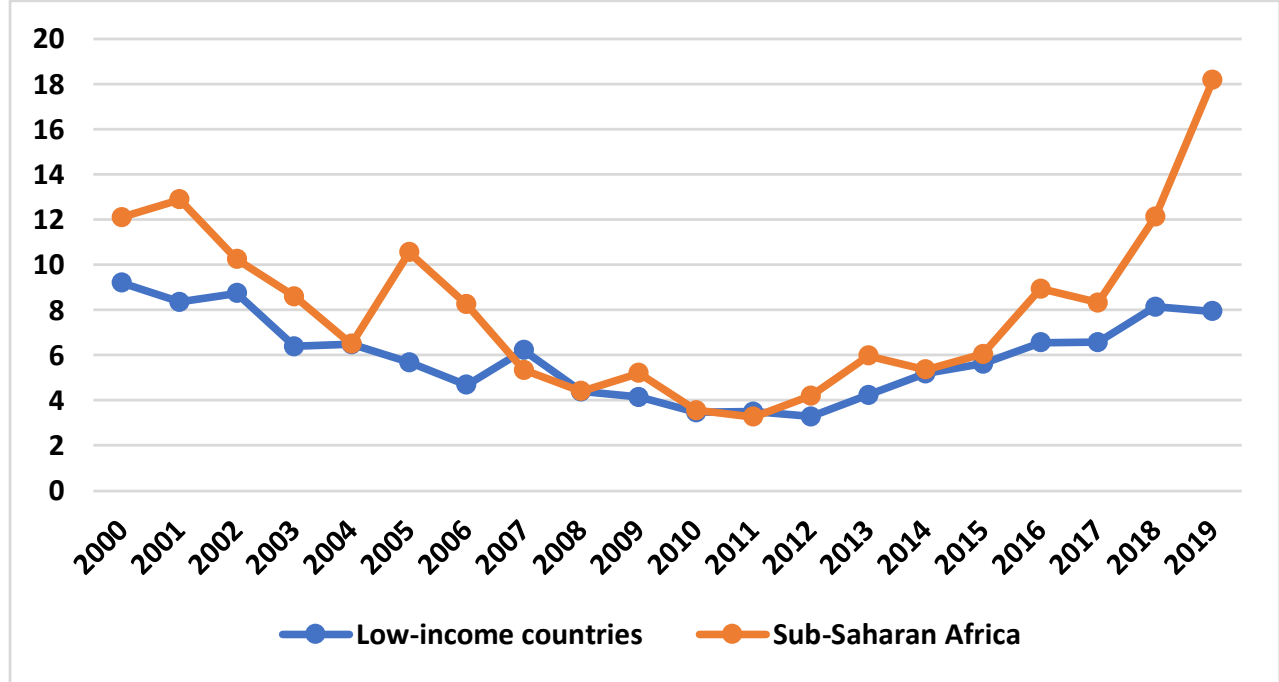

Source: Charted by author based on UNCTAD calculations based on data from WB, EIU, and IMF.

Notes: Figures for 2019 are UNCTAD estimates. Groups follow WB's definition.

This is of concern is Sub-Saharan Africa bears the heavier debt than Low-income group which around $12 \%$ in 2000 . The overall the orange line is not like to be bad over the period show, but badly increased sharply in 2019 at around over $18 \%$.
The status of Low-income group is similar that has a slight going down but the amount debt in 2019 is still high which is approximately $8 \%$. 
Figure 7. Redemption schedules for public external debt in developing countries, 2020 and 2021 (Trillions of current USD (Tril USD)

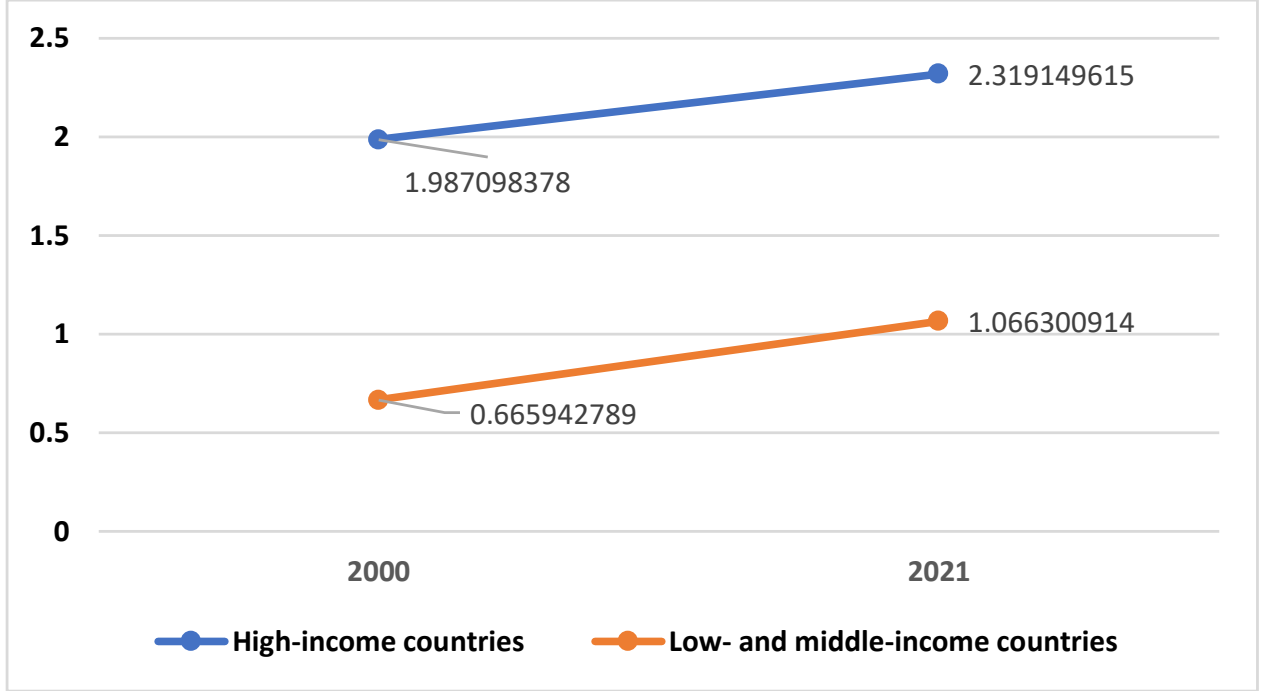

Source: Charted by author based on UNCTAD calculations based on WB, IIF, and IMF

Notes: Data refer to sovereign debt for high-income countries and public external debt for middle- and low-income countries. Country groups follow WB's definition.

Figure 7 gives us information about redemption schedules for public external debt of developing countries in 2020 and 2021. The highlight is both High-income countries and Low- and middle-income countries both increased the amount of redemption which is from around 2 to 2.32 tril USD and 0.67 to 1.07 tril USD in 2000 and 2021, respectively. This shows us that at least they have solution how to get resolved their external debt.

Tabel 1:

\begin{tabular}{|c|c|c|c|c|c|c|}
\hline & \multicolumn{3}{|l|}{ Figure 1} & \multicolumn{3}{|l|}{ Figure 2} \\
\hline Year & $\begin{array}{l}\text { PPG long- } \\
\text { term debt }\end{array}$ & $\begin{array}{l}\text { PNG long- } \\
\text { term debt }\end{array}$ & Short-term debt & $\begin{array}{l}\text { PPG long- } \\
\text { term debt }\end{array}$ & $\begin{array}{l}\text { PNG long- } \\
\text { term debt }\end{array}$ & $\begin{array}{l}\text { Short-term } \\
\text { debt }\end{array}$ \\
\hline 2000 & $1,395.9455$ & 494.3516 & 335.4541 & 20.8161419 & 7.75189111 & 15.25062513 \\
\hline 2001 & $1,371.7557$ & 488.1747 & 359.5324 & 20.286961 & 7.59744526 & 5.5856603 \\
\hline 2002 & $1,407.3358$ & 461.8077 & 355.3977 & 20.5039079 & 7.07158622 & 5.43178315 \\
\hline 2003 & $1,545.6382$ & 584.9265 & 480.3808 & 18.8051821 & 7.84970646 & 6.43679216 \\
\hline 2004 & $1,577.9399$ & 657.5169 & 561.7141 & 17.7173322 & 7.39333756 & 66.30788097 \\
\hline 2005 & $1,470.1889$ & 785.1800 & 640.6038 & 13.7972682 & 7.37959017 & 76.01409849 \\
\hline 2006 & $1,448.7168$ & 998.5228 & 750.4916 & 11.4056755 & 7.87335973 & 35.91171437 \\
\hline 2007 & $1,605.8509$ & $1,290.9695$ & 977.6795 & 10.2875854 & 8.2820149 & 6.26705899 \\
\hline 2008 & $1,668.0575$ & $1,559.7595$ & 996.9018 & 8.87248903 & 8.33133033 & 35.31748057 \\
\hline 2009 & $1,800.9256$ & $1,587.9230$ & $1,046.9853$ & 9.90275149 & 8.7641803 & 5.76989989 \\
\hline 2010 & $1,946.9037$ & $1,768.3491$ & $1,541.3540$ & 8.80458096 & 8.02381108 & 6.98757524 \\
\hline 2011 & $2,091.8617$ & $2,178.6902$ & $1,877.8135$ & 7.98477588 & 8.34015501 & 7.18313875 \\
\hline 2012 & $2,292.2495$ & $2,485.1205$ & $2,091.8027$ & 8.17533749 & 8.88998321 & 17.47863113 \\
\hline 2013 & $2,518.2470$ & $2,733.8866$ & $2,493.5094$ & 8.50254462 & 9.24826146 & 68.4335648 \\
\hline
\end{tabular}


"The New Manifestations of External Debt in Developing Countries From 2000 to 2019"

\begin{tabular}{|l|l|l|l|l|l|l|}
\hline 2014 & $2,695.0833$ & $2,956.6368$ & $2638.007746508+E 2: E 17$ & 8.79768935 & 9.66763667 & 8.62385432 \\
\hline 2015 & $2,736.6275$ & $2,989.3618$ & $2,137.3694$ & 9.37589844 & 10.3572354 & 7.3776565 \\
\hline 2016 & $2,957.0005$ & $3,198.4693$ & $2,111.4723$ & 10.1275457 & 11.0847743 & 7.26256473 \\
\hline 2017 & $3,359.0333$ & $3,286.7712$ & $2,457.0999$ & 10.5253235 & 10.4214191 & 7.73893258 \\
\hline 2018 & $3,520.1340$ & $3,334.1890$ & $2,700.1349$ & 10.4064571 & 9.96836894 & 8.01523786 \\
\hline 2019 & $3,700.1479$ & $3,370.3193$ & $2,754.1564$ & 10.6101332 & 9.7737898 & 7.93008076 \\
\hline
\end{tabular}

Tabel 2:

Source: refer the source of figure, respectively

Figure 3

\begin{tabular}{|c|c|c|c|c|c|c|}
\hline & $\begin{array}{l}\text { PPG long-term } \\
\text { debt, } 2000\end{array}$ & $\begin{array}{ll}\text { PNG } & \text { long } \\
\text { term } & \text { debt } \\
2000 & \end{array}$ & $\begin{array}{l}\text { Short-term } \\
\text { debt, } 2000\end{array}$ & $\begin{array}{l}\text { PPG long-term debt, } \\
2018\end{array}$ & $\begin{array}{l}\text { PNG long-term } \\
\text { debt, } 2018\end{array}$ & $\begin{array}{l}\text { Short-term } \\
\text { debt, } 2018\end{array}$ \\
\hline $\begin{array}{l}\text { East and } \\
\text { South-East } \\
\text { Asia and } \\
\text { Oceania }\end{array}$ & 271.7180739 & 147.155105 & 61.18228244 & 668.139568 & 1235.7944 & 1695.086293 \\
\hline $\begin{array}{l}\text { Latin America } \\
\text { and the } \\
\text { Caribbean }\end{array}$ & 424.742066 & 241.773565 & 116.5088275 & 1022.829805 & 789.8518372 & 371.1393743 \\
\hline $\begin{array}{l}\text { Northern } \\
\text { Africa and } \\
\text { Western Asia }\end{array}$ & 285.3698304 & 41.9212795 & 97.01451074 & 837.271143 & 467.5327057 & 335.0157218 \\
\hline $\begin{array}{l}\text { Europe and } \\
\text { Central Asia }\end{array}$ & 121.8617294 & 33.73863747 & 24.1457816 & 307.8805929 & 452.1863146 & 98.12149046 \\
\hline Southern Asia & 139.3455632 & 18.513781 & 9.725617371 & 327.7405861 & 255.795124 & 134.5274307 \\
\hline $\begin{array}{l}\text { Sub-Saharan } \\
\text { Africa }\end{array}$ & 152.9082218 & 11.2492533 & 26.87705442 & 356.2722684 & 133.0286118 & 66.24457853 \\
\hline Figure 4 & & & & & & \\
\hline & $\begin{array}{l}\text { Official } \\
\text { creditors } \\
\text { bilateral }\end{array}$ & $\begin{array}{l}\text { Official } \\
\text { creditors } \\
\text { multilateral }\end{array}$ & $\begin{array}{l}\text { Private } \\
\text { creditors } \\
\text { bonds }\end{array}$ & $\begin{array}{l}\text { Private creditors - } \\
\text { commercialbanks }\end{array}$ & $\begin{array}{l}\text { Private } \\
\text { creditors } \\
\text { other }\end{array}$ & \\
\hline 2000 & $4.19448 \mathrm{E}+11$ & $3.16797 \mathrm{E}+11$ & $3.14115 \mathrm{E}+11$ & $1.21944 \mathrm{E}+11$ & 65114979113 & \\
\hline 2009 & $3.29031 \mathrm{E}+11$ & $4.26128 \mathrm{E}+11$ & $4.4367 \mathrm{E}+11$ & $2.1658 \mathrm{E}+11$ & 37370892098 & \\
\hline 2018 & $4.37278 \mathrm{E}+11$ & $6.53758 \mathrm{E}+11$ & $1.35505 \mathrm{E}+12$ & $3.62414 \mathrm{E}+11$ & 76358045190 & \\
\hline
\end{tabular}

Source: refer the source of figure, respectively 
Tabel 3:

Figure 5

Figure 6

\begin{tabular}{|c|c|c|c|c|c|c|c|}
\hline ear & $\begin{array}{l}\text { All } \\
\text { developing } \\
\text { and transition } \\
\text { countries }\end{array}$ & $\begin{array}{l}\text { High-income } \\
\text { developing } \\
\text { countries }\end{array}$ & $\begin{array}{l}\text { Middle- } \\
\text { income } \\
\text { developing } \\
\text { countries }\end{array}$ & $\begin{array}{l}\text { Low-income } \\
\text { developing } \\
\text { countries }\end{array}$ & SIDS & $\begin{array}{l}\text { Low-income } \\
\text { countries }\end{array}$ & $\begin{array}{l}\text { Sub-Saharan } \\
\text { Africa }\end{array}$ \\
\hline 000 & & 10.27403489 & 12.68036651 & & 13.48843967 & & \\
\hline 2001 & 10.28696221 & 9.962073984 & 12.89407906 & 6.67366952 & 11.26412015 & 8.35996909 & 12.88 \\
\hline 002 & 9. & 416698 & 247 & .359450964 & 13.83178771 & 8.7384917 & 10.24089758 \\
\hline 003 & 9.06 & 8.307082828 & 13.2 & 4.056925877 & 12.46202626 & 6.389845234 & 8.600968181 \\
\hline 2004 & & 5.809839789 & 9.824663161 & 3.906297261 & 11.10977144 & 6.485991669 & 6.4993 \\
\hline 005 & 6.00 & 4.621897229 & 9.28 & 3.630532482 & 10.782 & 5.680678631 & 287 \\
\hline 2006 & 5.96 & 4.992784569 & 7.72 & 3.610281861 & 7.8825 & 4.673939679 & 8240 \\
\hline 007 & 3.8 & 3.44005077 & 5.30 & 4.049678869 & 811 & 38 & 602 \\
\hline 2008 & 3.62 & 3.038882943 & 4.669841512 & 3.793465664 & 0.4175000 & 4.394375867 & 4.402998000 \\
\hline 2009 & 3.7 & 3.097152027 & 4.804111994 & 3.949970426 & 9.668639319 & 4.146903417 & 5.202267733 \\
\hline 010 & 19 & 2.508374258 & 67 & 32454 & 42 & 25 & 3.5 \\
\hline 201 & & 2.284500555 & 7255 & 3.044243692 & 7.054816621 & & 7746 \\
\hline 2012 & 2.49 & 2.203112806 & 3.1312 & 2.536715547 & 6.016876107 & 3.274798061 & 4.208781792 \\
\hline 3 & 2.7 & 2.15 & +0 & 3.441960676 & 4.870231054 & 4.237180 & 5.973303986 \\
\hline 2014 & 3.317437322 & 2.023367155 & 5.222456865 & 4.297076132 & 6.296039368 & 5.193928919 & 5.354363962 \\
\hline 2015 & 4.278401927 & 3.183886106 & 4.856615218 & 4.841918069 & 7.980253633 & 5.61674086 & 6.054125858 \\
\hline 2016 & 4.42 & 3.38 & 6.252252 & 6.18498201 & 11.54827 & 6.560471699 & 8.947321248 \\
\hline 2017 & 4.195620649 & 3.513795774 & 5.19780792 & 5.587473599 & 9.040472052 & 6.574846431 & 8.33017288 \\
\hline 2018 & 4.59051868 & 3.366666947 & 5.589184655 & 6.727135429 & 7.892670891 & 8.143846808 & 12.11628208 \\
\hline 2019 & 4.883392258 & 3.408255995 & 6.85743426 & 7.010994118 & 8.230167772 & 7.941943658 & 18.17377152 \\
\hline
\end{tabular}

Source: refer the source of figure, respectively

Tabel 4:

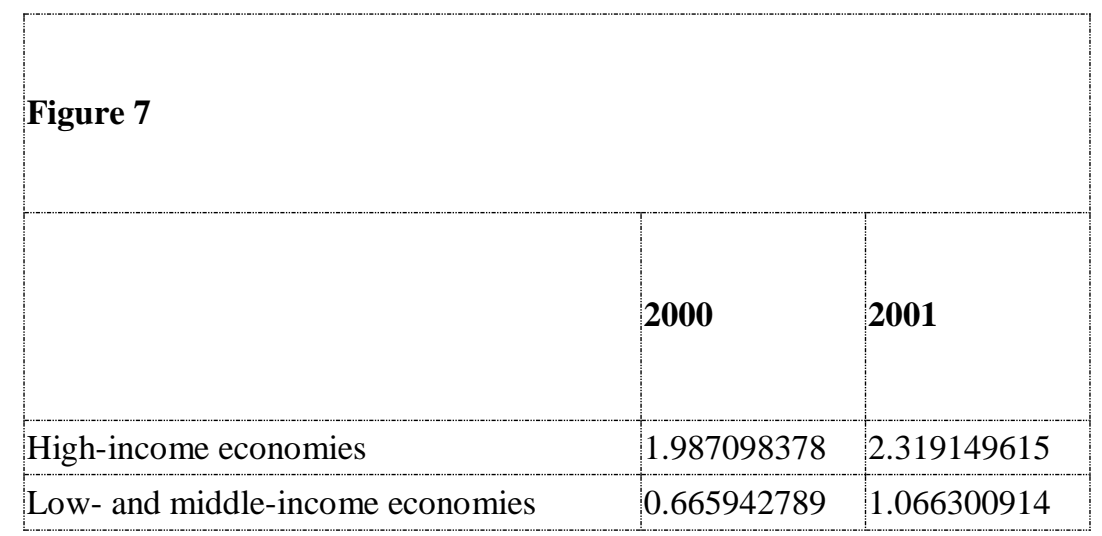

Source: refer the source of figure, respectively 
Table 5: External debt of developing countries

(Billions of United States dollars)

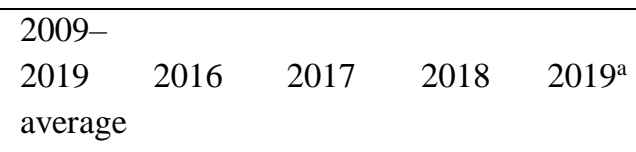

All developing countries
Total external debt stocks ${ }^{\mathrm{b}}$
Long-term external debt
Public and publicly guaranteed debt/long-term
external debt
Private non-guaranteed debt/long-term external debt
Short-term external debt
Total external debt service
Debt ratio

Total external debt/GDP

Total external debt/exports ${ }^{\mathrm{c}}$

Total debt service/GDP

Total debt service/exports ${ }^{\mathrm{c}}$

Reserves/short-term debt

Debt service on public and publicly guaranteed debt/government revenue

High-income developing economies

Total external debt stocks ${ }^{b}$

Long-term external debt

Public and publicly guaranteed debt/long-term external debt

Private non-guaranteed debt/long-term external debt Short-term external debt

Total external debt service

\section{Debt ratio ${ }^{c}$}

Total external debt/GDP

Total external debt/exports ${ }^{\mathrm{d}}$

Total debt service/GDP

Total debt service/exports ${ }^{\mathrm{d}}$

Reserves/short-term debt

Debt service on public and publicly guaranteed debt/government revenue

$\begin{array}{lllllllll}7 & 722.0 & 8 & 387.6 & 9 & 233.7 & 9 & 712.5 & 10\end{array}$

057.0

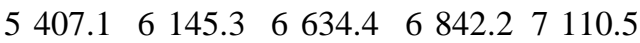

$49.7 \% \quad 48.1 \% \quad 50.6 \% \quad 51.4 \% \quad 52.0 \%$

$50.3 \% \quad 51.9 \% \quad 49.4 \% \quad 48.6 \% \quad 48.0 \%$

$\begin{array}{llllllllll}2 & 166.8 & 2 & 110.4 & 2 & 455.8 & 2 & 698.8 & 2 & 752.8\end{array}$

$\begin{array}{lllllllll}923.6 & 1 & 087.0 & 1 & 145.0 & 1 & 271.0 & 1 & 328.9\end{array}$

$\begin{array}{lllll}26.9 \% & 28.9 \% & 29.1 \% & 28.9 \% & 29.0 \% \\ 94.8 \% & 113.5 \% & 110.9 \% & 105.1 \% & 110.6 \% \\ 3.2 \% & 3.7 \% & 3.6 \% & 3.8 \% & 3.9 \% \\ 11.4 \% & 14.7 \% & 13.7 \% & 13.8 \% & 14.6 \% \\ 354.6 \% & 334.0 \% & 302.5 \% & 273.6 \% & 278.8 \%\end{array}$

$3.7 \% \quad 4.2 \% \quad 4.1 \% \quad 4.5 \% \quad 4.7 \%$

$\begin{array}{llllllllll}5 & 072.9 & 5 & 523.9 & 6 & 160.2 & 6 & 593.1 & 6 & 768.7\end{array}$

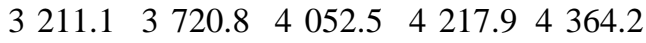

$\begin{array}{lllll}44.7 \% & 43.0 \% & 44.9 \% & 46.0 \% & 47.0 \%\end{array}$

$55.3 \% \quad 57.0 \% \quad 55.1 \% \quad 54.0 \% \quad 53.0 \%$

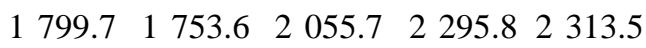

$\begin{array}{lllll}591.7 & 727.4 & 780.2 & 838.7 & 871.3\end{array}$

$\begin{array}{lllll}25.4 \% & 27.1 \% & 27.8 \% & 27.9 \% & 28.0 \%\end{array}$

$\begin{array}{llllll}88.2 \% & 103.5 \% & 104.0 \% & 101.4 \% & 106.3 \%\end{array}$

$3.0 \% \quad 3.6 \% \quad 3.5 \% \quad 3.6 \% \quad 3.7 \%$

$10.4 \% \quad 13.6 \% \quad 13.2 \% \quad 12.9 \% \quad 13.7 \%$

$329.9 \% \quad 311.2 \% \quad 275.0 \% \quad 244.3 \% \quad 245.7 \%$

$\begin{array}{lllll}2.7 \% & 3.0 \% & 3.2 \% & 3.1 \% & 3.0 \%\end{array}$

$\begin{array}{lllll}1590.1 & 1747.8 & 1948.2 & 2051.6 & 2175.2 \\ 1300.7 & 1447.3 & 1606.4 & 1702.1 & 1803.1 \\ 65.5 \% & 64.1 \% & 65.7 \% & 66.2 \% & 66.1 \% \\ 34.5 \% & 35.9 \% & 34.3 \% & 33.8 \% & 33.9 \% \\ 241.5 & 252.6 & 287.1 & 292.7 & 308.6 \\ 177.9 & 225.5 & 213.9 & 241.1 & 289.7 \\ & & & & \\ 26.0 \% & 27.1 \% & 27.8 \% & 28.4 \% & 28.4 \% \\ 100.3 \% & 121.2 \% & 117.0 \% & 110.5 \% & 117.5 \%\end{array}$


“The New Manifestations of External Debt in Developing Countries From 2000 to 2019"

Total debt service/GDP

Total debt service/exports ${ }^{\mathrm{d}}$

Reserves/short-term debt

Debt service on public and publicly guaranteed debt/government revenue

Low-income developing economies

Total external debt stocks ${ }^{b}$

Long-term external debt

Private non-guaranteed debt/long-term external debt Short-term external debt

Total external debt service

\section{Debt ratio}

Total external debt/GDP

Total external debt/exports ${ }^{\mathrm{d}}$

Total debt service/GDP

Total debt service/exports ${ }^{\mathrm{d}}$

Reserves/short-term debt

Debt service on public and publicly guaranteed debt/government revenue

\section{Economies in transition}

Total external debt stocks ${ }^{b}$

Long-term external debt

Private non-guaranteed debt/long-term external debt

Short-term external debt

Total external debt service

Debt ratio ${ }^{c}$

Total external debt/GDP

Total external debt/exports ${ }^{\mathrm{d}}$

Total debt service/GDP

Total debt service/exports ${ }^{\mathrm{d}}$

Reserves/short-term debt

Debt service on public and publicly guaranteed

debt/government revenue

Least developed countries

Total external debt stocks ${ }^{b}$

Long-term external debt

l'ublic and

Private non-guaranteed debt/long-term external debt

Short-term external debt

Total external debt Service

Debt ratio ${ }^{c}$

Total external debt/GDP

Total external debt/exports ${ }^{\mathrm{d}}$

Total debt service/GDP

Total debt service/exports ${ }^{\mathrm{d}}$

$\begin{array}{lllll}2.8 \% & 3.5 \% & 3.1 \% & 3.3 \% & 3.8 \% \\ 11.1 \% & 15.6 \% & 12.8 \% & 13.0 \% & 15.6 \% \\ 464.7 \% & 418.9 \% & 405.5 \% & 385.5 \% & 402.3 \%\end{array}$

$\begin{array}{lllll}6.3 \% & 7.7 \% & 6.7 \% & 7.4 \% & 8.9 \%\end{array}$

$\begin{array}{lllll}115.5 & 129.1 & 143.1 & 148.7 & 163.1\end{array}$

$\begin{array}{lllll}98.8 & 112.1 & 124.9 & 130.6 & 143.0\end{array}$

$\begin{array}{lllll}91.4 \% & 90.1 \% & 90.4 \% & 90.7 \% & 87.4 \%\end{array}$

$8.6 \% \quad 9.9 \% \quad 9.6 \% \quad 9.3 \% \quad 12.6 \%$

$\begin{array}{lllll}8.0 & 8.7 & 9.3 & 9.2 & 8.6\end{array}$

$\begin{array}{lllll}5.0 & 5.9 & 6.3 & 7.6 & 9.2\end{array}$

$\begin{array}{lllll}29.6 \% & 32.0 \% & 33.3 \% & 31.9 \% & 33.1 \% \\ 141.6 \% & 181.7 \% & 170.9 \% & 158.8 \% & 171.1 \% \\ 1.2 \% & 1.5 \% & 1.5 \% & 1.7 \% & 1.9 \% \\ 6.2 \% & 8.6 \% & 7.9 \% & 8.4 \% & 10.1 \% \\ 658.3 \% & 509.8 \% & 561.0 \% & 564.5 \% & 641.7 \%\end{array}$

$\begin{array}{lllll}5.3 \% & 6.6 \% & 6.6 \% & 8.1 \% & 7.9 \%\end{array}$

$\begin{array}{lllll}943.5 & 986.7 & 982.1 & 919.0 & 950.0\end{array}$

$\begin{array}{lllll}796.6 & 865.1 & 850.6 & 791.7 & 800.2\end{array}$

$39.2 \% \quad 37.5 \% \quad 43.2 \% \quad 41.6 \% \quad 41.2 \%$

$60.8 \% \quad 62.5 \% \quad 56.8 \% \quad 58.4 \% \quad 58.8 \%$

$\begin{array}{lllll}117.7 & 95.4 & 103.7 & 101.2 & 122.1\end{array}$

$\begin{array}{lllll}149.0 & 128.1 & 144.5 & 183.7 & 158.8\end{array}$

$\begin{array}{lllll}40.4 \% & 53.5 \% & 44.8 \% & 39.6 \% & 39.7 \% \\ 129.3 \% & 184.2 \% & 149.9 \% & 116.2 \% & 122.6 \% \\ 6.5 \% & 6.9 \% & 6.6 \% & 7.9 \% & 6.6 \% \\ 20.7 \% & 23.9 \% & 22.1 \% & 23.2 \% & 20.5 \% \\ 500.2 \% & 514.3 \% & 541.7 \% & 593.6 \% & 571.4 \%\end{array}$

$\begin{array}{lllll}6.4 \% & 7.4 \% & 6.2 \% & 10.3 \% & 9.4 \%\end{array}$

$\begin{array}{lllll}272.2 & 309.4 & 336.4 & 356.6 & 378.0\end{array}$

$\begin{array}{lllll}230.5 & 267.5 & 290.1 & 312.8 & 330.8\end{array}$

$84.8 \% \quad 82.1 \% \quad 84.4 \% \quad 84.3 \% \quad 85.1 \%$

$\begin{array}{lllll}15.2 \% & 17.9 \% & 15.6 \% & 15.7 \% & 14.9 \%\end{array}$

$\begin{array}{lllll}27.9 & 29.7 & 33.3 & 30.1 & 29.5\end{array}$

$\begin{array}{lllll}17.9 & 21.3 & 22.5 & 25.9 & 33.5\end{array}$

$30.3 \% \quad 32.1 \% \quad 31.1 \% \quad 33.9 \% \quad 34.6 \%$

$129.2 \% \quad 163.1 \% \quad 151.2 \% \quad 148.7 \% \quad 159.8 \%$

$\begin{array}{lllll}1.9 \% & 2.2 \% & 2.1 \% & 2.5 \% & 3.1 \%\end{array}$

$\begin{array}{lllll}8.5 \% & 11.4 \% & 10.3 \% & 11.0 \% & 14.4 \%\end{array}$ 
“The New Manifestations of External Debt in Developing Countries From 2000 to 2019"

\begin{tabular}{|c|c|c|c|c|c|}
\hline Reserves/short-term debt & $404.1 \%$ & $406.1 \%$ & $379.6 \%$ & $414.8 \%$ & $449.2 \%$ \\
\hline $\begin{array}{l}\text { Debt service on public and publicly guaranteed } \\
\text { debt/government revenue }\end{array}$ & $8.5 \%$ & $10.8 \%$ & $9.2 \%$ & $11.7 \%$ & $17.2 \%$ \\
\hline \multicolumn{6}{|l|}{ Small island developing States } \\
\hline Total external debt stocks ${ }^{b}$ & & 43.8 & 45.7 & 48.6 & 50.4 \\
\hline \multirow[t]{2}{*}{ Long-term external debt } & 29.9 & 31.4 & 32.5 & 35.3 & 37.1 \\
\hline & $65.7 \%$ & $70.3 \%$ & $71.9 \%$ & $67.8 \%$ & $64.9 \%$ \\
\hline Private non-guaranteed debt/long-term external & $34.3 \%$ & $29.7 \%$ & $28.1 \%$ & $32.2 \%$ & $35.1 \%$ \\
\hline Short-term external debt & 9.3 & 10.7 & 11.5 & 11.7 & 11.5 \\
\hline Total external debt service & 6.1 & 5.0 & 6.5 & 6.6 & 7.0 \\
\hline \multicolumn{6}{|l|}{ Debt ratio ${ }^{c}$} \\
\hline Total external debt/GDP & $55.0 \%$ & $60.7 \%$ & $60.5 \%$ & $60.5 \%$ & $61.7 \%$ \\
\hline Total external debt/exports ${ }^{\mathrm{d}}$ & $155.3 \%$ & $171.0 \%$ & $166.9 \%$ & $165.2 \%$ & $172.4 \%$ \\
\hline Total debt service/GDP & $8.2 \%$ & $6.9 \%$ & $8.6 \%$ & $8.2 \%$ & $8.5 \%$ \\
\hline Total debt service/exports ${ }^{\mathrm{d}}$ & $24.7 \%$ & $21.8 \%$ & $23.4 \%$ & $22.9 \%$ & $24.3 \%$ \\
\hline Reserves/short-term debt & $235.0 \%$ & $208.4 \%$ & $205.3 \%$ & $200.8 \%$ & $208.8 \%$ \\
\hline \multicolumn{6}{|l|}{ Debt service on public and publicly guaranteed $\mathrm{d}$} \\
\hline government revenue & $9.7 \%$ & $13.5 \%$ & $11.1 \%$ & $9.8 \%$ & $10.0 \%$ \\
\hline
\end{tabular}

Source: UNCTAD secretariat calculations, based on WB, the IMF and national sources.

\section{DISCUSSION AND CONCLUSION}

Main point is the external debt is trended by groups of country. The detail are external debt stocks is while the external debt stocks of PPG long term debt, PNG long term debt rose between 2000 and 2019, short term debt was fluctuated at the same period. The percentage of GDP of External debt stocks is while PPG long term debt decreased, PNG long term debt and short term debt slightly went up between 2000 and 2019. External debt stocks in developing countries by region is the concern is East and South-East Asia and Oceania and Latin America and the Caribbean have exchange the top and second position of highest amount in both 2018 and 2000. Long-term external PPG debt by creditor is Private creditors - bonds helds the biggest amount for average three years, especially $1.35505 \mathrm{E}+12 \%$ in 2018. Debt service on long-term external PPG debt is the status bebt of developing countries in detail. In which the overall is SIDS is helds the biggest amount of debt between 2000 and 2019. Debt service on long-term external PPG debt, Low-income group and Sub-Saharan Africa group is Sub-Saharan Africa bears the heavier debt than Low-income group which around $12 \%$ in 2000. Redemption schedules for public external debt is The highlight is both High-income countries and Low- and middle-income countries both increased the amount of redemption which is from around 2 to 2.32 tril USD and 0.67 to 1.07 tril USD in 2000 and 2021, respectively. This shows us that at least they have solution how to get resolved their external debt.

Acknowledgement: This research is funded by Van Lang University.

\section{REFERENCE}

1. Keshmeer Makun, 2021. External debt and economic growth in Pacific Island countries: A linear and nonlinear analysis of Fiji Islands. The Journal of Economic Asymmetries. Volume 23, June 2021, e00197. https://doi.org/10.1016/j.jeca.2021.e00197

2. Stucy of Marin Ferry, MarcRaffinot, Baptiste Venet, 2021. Does debt relief "irresistibly attract banks as honey attracts bees"? Evidence from low-income countries' debt relief programs. International Review of Law and Economics. Volume 66, June 2021, 105978.

https://doi.org/10.1016/j.irle.2021.105978

3. Gatien Bon, Gong Cheng, 2021. Understanding China's role in recent debt relief operations: A case study analysis. International Economics. Volume 166, August 2021, Pages 23-41.

https://doi.org/10.1016/j.inteco.2021.02.004

4. Zhenbing Yang, Zhuo Chen, Qi Shi al et, 2021. Does outward foreign direct investment increase debt ratio? Firm-level evidence from China. Structural Change and Economic Dynamics. Volume 57, June 2021, Pages 1-12.

https://doi.org/10.1016/j.strueco.2021.01.004

5. David Simon in 2020. Debt. International Encyclopedia of Human Geography (Second Edition). 2020, Pages 173-179. https://doi.org/10.1016/B978-0-08-1022955.10039-3

6. SungY. Kwack, 1983. Developments in and Prospects for External Debt Position and Burden of 
“The New Manifestations of External Debt in Developing Countries From 2000 to 2019"

Developing Countries: The Case of Korea. Journal of Policy Modeling 5(3):443-459(1983).

7. Xuguang Simon Sheng, Rubena Sukaj, 2020. Identifying External Debt Shocks in Low- and Middle-Income Countries. Journal Pre-proofs. S0261-5606(20)30239-4.

https://doi.org/10.1016/j.jimonfin.2020.102283
8. Samson Edo, Nneka Esther Osadolor, Isuwa Festus Dading, 2020. Growing External Debt and Declining Export: The Concurrent Impediments in Economic Growth of Sub-Saharan African Countries. Journal Pre-proof. S2110-7017(19) 30215-X.

https://doi.org/10.1016/j.inteco.2019.11.013 